\title{
Wpływ liczby warstw i sposobu obróbki ubytkowej na twardość napoin z brązu
}

\author{
The influence of the number of layers and method of machining \\ on the hardness of bronze padding welds
}

\section{Streszczenie}

W artykule przedstawiono wpływ liczby warstw z brązu oraz sposobu i rodzaju obróbki ubytkowej na twardość napoiny. Badano warstwy z brązu cynowego ułożone na podłożu ze stali 45. Do nałożenia napoin użyto metody MIG. Wyznaczano twardość dla napoin jedno- i dwuwarstwowych oraz porównywano ją z twardością próbki wykonanej z brązu o tym samym składzie chemicznym i obrabianą w taki sam sposób, a także $z$ danymi dostarczonymi przez producenta drutu elektrodowego. Wyniki wskazują na wpływ zarówno liczby warstw, jak i sposobu i rodzaju obróbki na twardość napoin.

Słowa kluczowe: napawanie, brąz aluminiowy, MIG
Abstract

This article presents the influence of the number of layers and the method of machining on properties of bronze padding welds deposited on steel 45 with MIG method. As a coating material applied tin bronze. The hardness was determined for the single- and double-layer of padding welds.

Properties of obtained padding welds was compared with properties of filler material. The results show the influence of both the number of layers, as well as the method and type of treatment on the hardness of the padding welds.

Keywords: hardfacing, tin bronze, MIG

\section{Wstęp}

Nanoszenie powłok metodami spawalniczymi jest jednym ze sposobów nadawania częściom maszyn i urządzeń odpowiednich właściwości eksploatacyjnych. Napawanie powierzchni stosuje się nie tylko w celu przywrócenia częściom maszyn pierwotnych właściwości utraconych w wyniku zużycia, ale także w celu nadania powierzchniom nowo wytwarzanych elementów odpowiednich cech użytkowych.

Przykładem materiału, który może być do tego celu wykorzystany, jest brąz. Napawanie brązem znajduje szerokie zastosowanie między innymi przy regeneracji powierzchni ślizgowych łożysk i suwaków różnych elementów maszyn i urządzeń oraz powierzchni uszczelniających w przemysłowej armaturze wodnej lub parowej.

Do badań wybrano dwa materiały o odmiennych właściwościach, tzn. brąz cynowy CuSn6 jako materiał dodatkowy i stal 45 jako materiał podstawowy. Typowymi zastosowaniami przedstawionego w pracy brązu CuSn6 są elementy łożysk ślizgowych i powierzchnie odporne na korozję, natomiast stal 45 jest powszechnie wykorzystywana w produkcji części maszyn.

\section{Stanowisko badawcze i próbki do badań}

Napoiny z brązu wykonano, wykorzystując metodę napawania elektrodą topliwą w osłonie gazu obojętnego. Zastosowano drut elektrodowy z brązu cynowego CuSn6, o składzie chemicznym (\%) 6 Sn, 0,2 P, reszta $\mathrm{Cu}$, zgodnie z normą DIN 1733. Ściegi wykonywano drutem elektrodowym o średnicy $1,2 \mathrm{~mm}$. Jako materiał podłoża zastosowano stal węglową wyższej jakości 45 , w postaci próbek płaskich o wymiarach $420 \times 120 \times 23 \mathrm{~mm}$.

Napoiny wykonano na zmechanizowanym stanowisku badawczym (rys. 1) znajdującym się w Centrum Obsługi Badań Naukowych i Dydaktyki Wydziału Inżynierii Mechanicznej i Robotyki Akademii Górniczo-Hutniczej. W skład stanowiska wchodził półautomat spawalniczy OPTYMAG-501 ze sterowaniem

Dr inż. Tomasz Góral, prof. dr hab. inż. Andrzej Skorupa - Akademia Górniczo-Hutnicza w Krakowie. 
mikroprocesorowym. Uchwyt spawalniczy z dodatkową dyszą osłonową do wytworzenia poszerzonej strefy gazu osłonowego był nieruchomy względem torowiska, po którym poruszał się wózek z zadaną prędkością napawania, nastawianą z wykorzystaniem bezstopniowego regulatora napięcia zasilającego silnik napędowy wózka. Komputerowy przyrząd do monitorowania procesu spawania umożliwiał pomiar i rejestrację takich technologicznych parametrów napawania jak: natężenie prądu napawania $I_{n}$, napięcie łuku $U_{n}$ oraz prędkość napawania $\mathrm{v}_{\mathrm{n}}$. Podczas badań kontrolowano temperaturę $w$ sposób ciągły przy użyciu termopary umieszczonej w otworze wywierconym w próbce.

Proces napawania prowadzono $z$ zastosowaniem niewielkiego podgrzania wstępnego $\mathrm{w}$ zakresie $60 \div 100{ }^{\circ} \mathrm{C}$ w celu odparowania wilgoci powodującej porowatość napoin. Zmniejszenie głębokości wtopienia, a tym samym stopnia wymieszania brązu z metalem podłoża i jego utwardzenia wymaga, aby napięcie napawania $U_{n}$ i prąd napawania $I_{n}$ były możliwie małe, ale tak dobrane, aby uzyskać stabilny łuk. Na źródle spawalniczym nastawiano wymagane napięcie łuku, natomiast prąd napawania $I_{n}$ zadawano przez ustawienie odpowiednio małej prędkości podawania drutu elektrodowego. Zatem prędkość napawania $\mathrm{v}_{\mathrm{n}}$ ustalano tak, aby zapewnić stabilność prowadzenia procesu napawania i niewielką głębokość wtopienia [1,2].

Wykorzystując technologiczne parametry napawania zestawione $\mathrm{w}$ tablicy I, wykonano pojedyncze ściegi oraz napoiny jedno- i dwuwarstwowe. Napoiny w warstwie układano z zakładką wynoszącą połowę szerokości wcześniej ułożonego ściegu. Zastosowane parametry zapewniają wysoką wydajność napawania przy małym udziale materiału podłoża w napoinie wynoszącym ok. $5 \%$.

Przykładowe napoiny przedstawiono na rysunku 2.

Po napawaniu minimalna wysokość pojedynczego ściegu mierzona w przekrojach poprzecznych mikroskopem warsztatowym wyniosła $3 \mathrm{~mm}$, wysokość napoiny jednowarstwowej mierzona we wrębach pomiędzy ściegami 2,45 mm, a napoiny dwuwarstwowej $5,5 \mathrm{~mm}$. Maksymalna szerokość ściegu była równa $11 \mathrm{~mm}$.

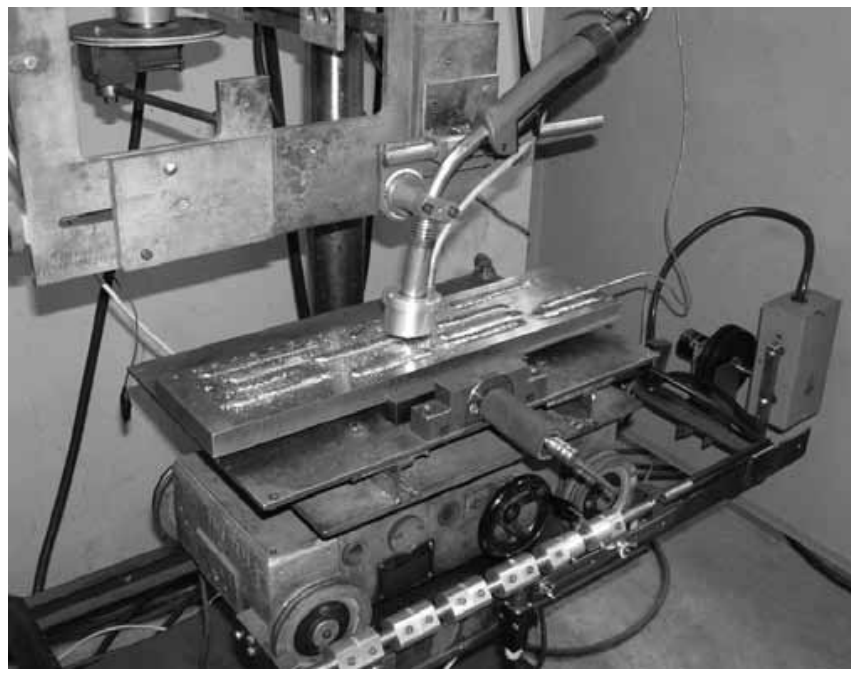

Rys. 1. Stanowisko badawcze

Fig. 1. The test stand

\section{Badania twardości}

Badania twardości obejmowały porównanie twardości pojedynczego ściegu z napoinami jedno- i dwuwarstwowymi. Ze względu na niewielką powierzchnię boczną przekrojów napoin pomiarów twardości dokonano metodą Vickersa, zgodnie z normą [3]. Posłużono się twardościomierzem uniwersalnym Vickers-Brinell HPO-250 z obciążeniem 49,03 N w jednostkach HV5/30 (z czasem obciążania $30 \mathrm{~s}$ ). Na podstawie wspomnianej normy [3] niepewność pomiaru przyjęto w przybliżeniu $\pm 10 \%$ zmierzonej wartości twardości.

Tablica I. Zestawienie technologicznych parametrów napawania zastosowanych do wykonania próbek

Table I. Summary of technological parameters of welding used to prepare the samples

\begin{tabular}{|c|c|}
\hline $\begin{array}{c}\text { Nazwa technologicznego } \\
\text { parametru napawania }\end{array}$ & Wartość \\
\hline $\begin{array}{c}\text { Prędkość podawania } \\
\text { drutu elektrodowego }\end{array}$ & $5,5 \mathrm{~m} / \mathrm{min}$ \\
\hline Napięcie łuku & $23 \mathrm{~V}$ \\
\hline Prędkość napawania & $3 \mathrm{~mm} / \mathrm{s}$ \\
\hline $\begin{array}{c}\text { Odległość rurki prądowej } \\
\text { od napawanego elementu }\end{array}$ & $18 \mathrm{~mm}$ \\
\hline Średnica drutu elektrodowego & $1,2 \mathrm{~mm}$ \\
\hline Rodzaj gazu osłonowego & argon $100 \%$ \\
\hline Przepływ gazu osłonowego & $16 \mathrm{dm}{ }^{3} / \mathrm{min}^{\circ}$ \\
\hline $\begin{array}{c}\text { Temperatura wstępnego } \\
\text { podgrzania (międzyściegowa) }\end{array}$ & $60 \div 200{ }^{\circ} \mathrm{C}$ \\
\hline Podziałka napawania & 0,5 \\
\hline
\end{tabular}

a)

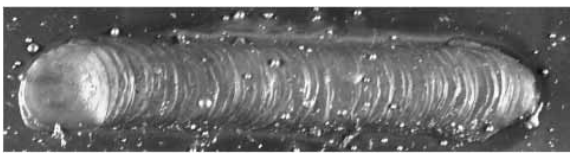

b)

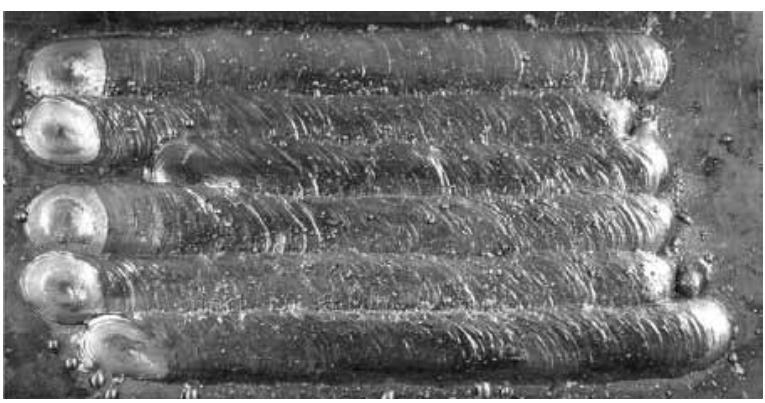

c)

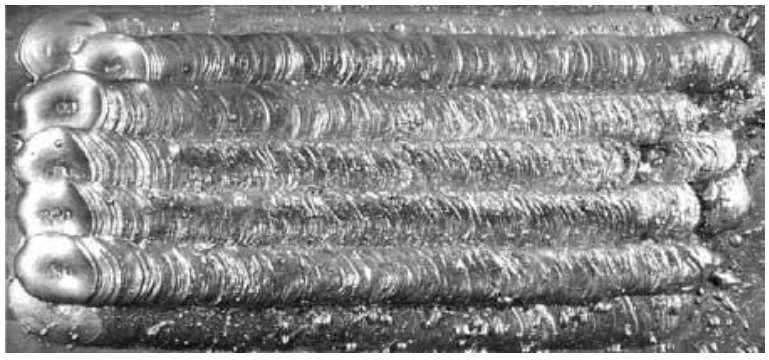

Rys. 2. Przykładowe napoiny: widok z góry pojedynczego ściegu (a), próbki jednowarstwowej (b) i dwuwarstwowej (c)

Fig. 2. Examples of the deposit: Top view of a single bead (a), the samples monolayer (b) and the bilayer (c) 
Pomiary twardości wykonano w pięciu przekrojach poprzecznych próbek. Powierzchnię przed pomiarem przygotowano przez frezowanie i następnie szlifowanie. W czasie frezowania zbierano warstwę materiału o grubości do $2 \mathrm{~mm}$, a przez szlifowanie usuwano warstwę o grubości co najwyżej do 0,2 mm, przy czym w jednym przejściu głębokość skrawania wynosiła $0,01 \mathrm{~mm}$. Szlifowanie miało jedynie na celu odpowiednie przygotowanie powierzchni próbek do pomiaru twardości.

Pomiary twardości zarówno dla próbek z pojedynczymi ściegami, jak i próbek z napoinami warstwowymi prowadzono $w$ ten sposób, że w każdym przekroju próbki dokonywano pięciu odcisków na przekroju porzecznym napoiny w jak największej odległości od materiału podłoża.

Wyniki pomiarów twardości na powierzchniach frezowanych i zabielonych zaprezentowano $\mathrm{w}$ postaci przedziału minimalnej i maksymalnej wartości znalezionej we wszystkich przekrojach (rys. 3). Na rysunku tym pominięto wyniki twardości dla skrajnych ściegów w dolnej warstwie dla napoiny dwuwarstwowej i pierwszego ściegu $w$ napoinie jednowarstwowej ze względu na większe głębokości wtopienia i większe wymieszanie materiału podłoża z brązem.

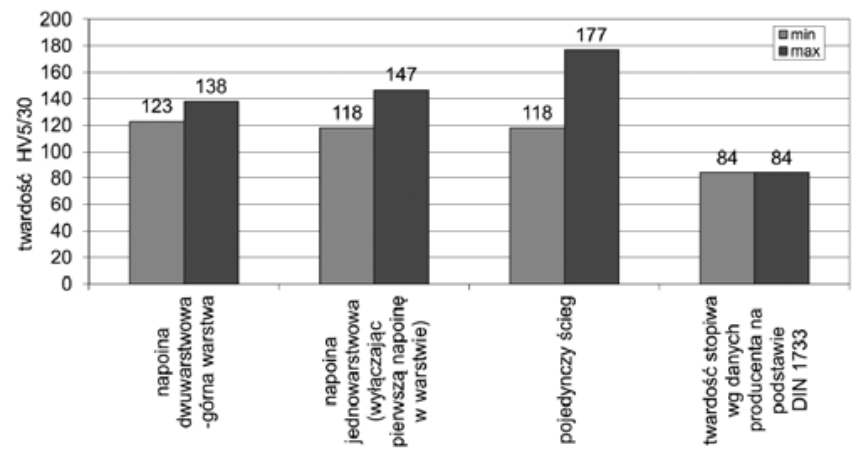

Rys. 3. Twardość warstw napoin z brązu po obróbce próbek przez frezowanie

Fig. 3. The hardness of the layers of of bronze padding welds treated by milling

Wartości minimalne twardości pojedynczych ściegów oraz warstw napoin są dość zbliżone do siebie. Najmniejsze wartości maksymalne ma zgodnie z oczekiwaniami górna warstwa napoiny dwuwarstwowej, warstwa ta bowiem nie miała w czasie jej nanoszenia bezpośredniego styku z materiałem podłoża. Większy rozstęp twardości i większe wartości twardości maksymalnych można zauważyć dla napoiny jednowarstwowej, co wynika z kontaktu brązu z materiałem podłoża podczas napawania i jego wymieszaniem ze stalą. Największy rozrzut twardości oraz najwyższą jej wartość ma pojedynczy ścieg, co spowodowane jest najprawdopodobniej znacznym wymieszaniem materiału podłoża z napoiną. Można też zauważyć, że twardości pojedynczego ściegu i napoin są wyższe od twardości stopiwa podawanej przez producenta drutu.

Na wartość twardości mierzonej w przekroju poprzecznym napawanej próbki może mieć wpływ nie tylko sposób napawania, ale również przebieg wcześniejszej obróbki mechanicznej przed pomiarami twardości. Jednoczesne frezowanie głowicą frezarską stali i brązu powoduje tępienie płytek głowicy w czasie obróbki utwardzonej strefy podspoinowej i linii przejścia. Im bardziej stępione narzędzie, tym większy zgniot. Również większemu zgniotowi sprzyjają małe prędkości skrawania i duży przekrój warstwy skrawanej. Frezowanie brązu stępionym narzędziem powodującym nagniatanie, a nie skrawanie, może powodować wzrost jego twardości o 1520\% [4]. $\mathrm{Na}$ rysunku 4 przedstawiono wpływ stopnia zgniotu na właściwości mechaniczne brązu o małej zawartości cyny [5]. Jak widać z tego rysunku, niewielki przyrost wartości zgniotu od 0 do $10 \%$ znacznie zwiększa twardość brązu, nawet o $40 \mathrm{HB}$.

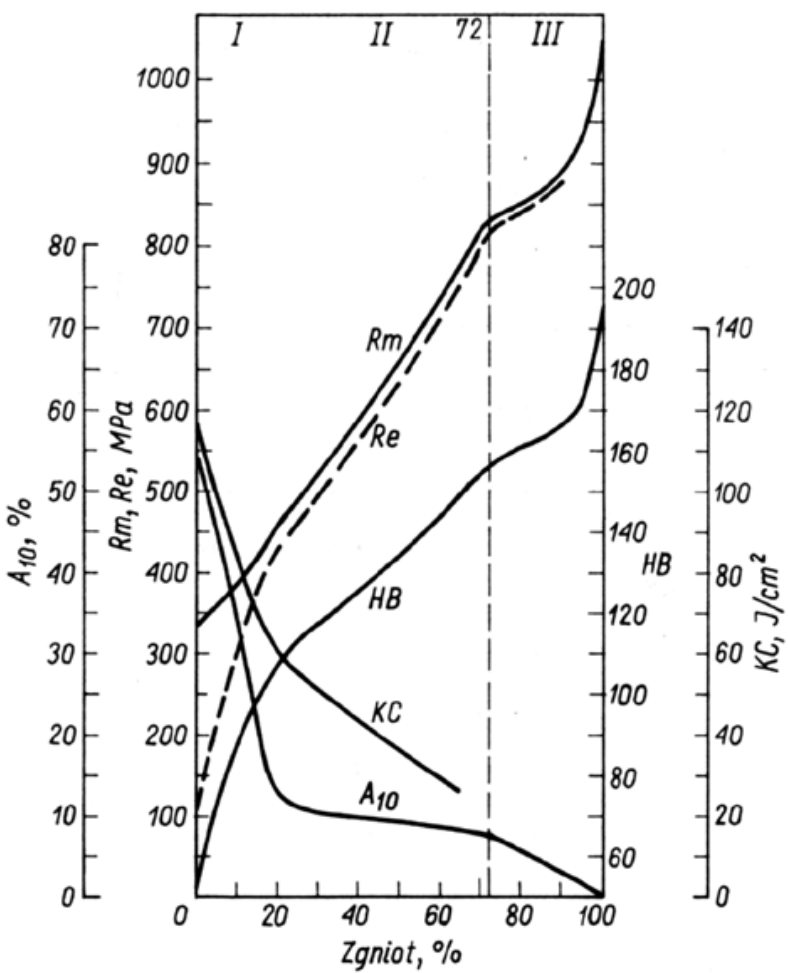

Rys. 4. Wpływ stopnia zgniotu na właściwości mechaniczne brązu o zawartości 5\% cyny [5]

Fig. 4. The effect of deformation on the mechanical properties of bronze containing $5 \%$ tin

Kolejne próby dotyczyły określenia wpływu sposobu obróbki szlifowaniem na twardość napoin. Wykorzystano do tego celu próbki z poprzedniego etapu badań. Obróbka odbywała się bez dalszego udziału frezowania. Jedną stronę przeszlifowano cztery razy, zbierając warstwę $0,05 \mathrm{~mm}$ w każdym przejściu tarczy, natomiast drugą stronę szlifowano, zbierając w jednym przejściu warstwę o grubości 0,01 mm dwadzieścia razy, tak aby uzyskać w obu przypadkach tę samą całkowitą grubość usuwanej warstwy. Dla napoin dwuwarstwowych mierzono twardość tylko w warstwie górnej napoiny.

Dla obu rodzajów napoin można zauważyć (rys. 5 i 6), że wartości twardości minimalnych i maksymalnych są większe dla szlifowania z głębokością skrawania $0,05 \mathrm{~mm}$ w jednym przejściu, niż w przypadku zbierania warstwy równej $0,01 \mathrm{~mm}$. Jest to spowodowane opisanym wyżej wpływem zgniotu na twardość brązu. 


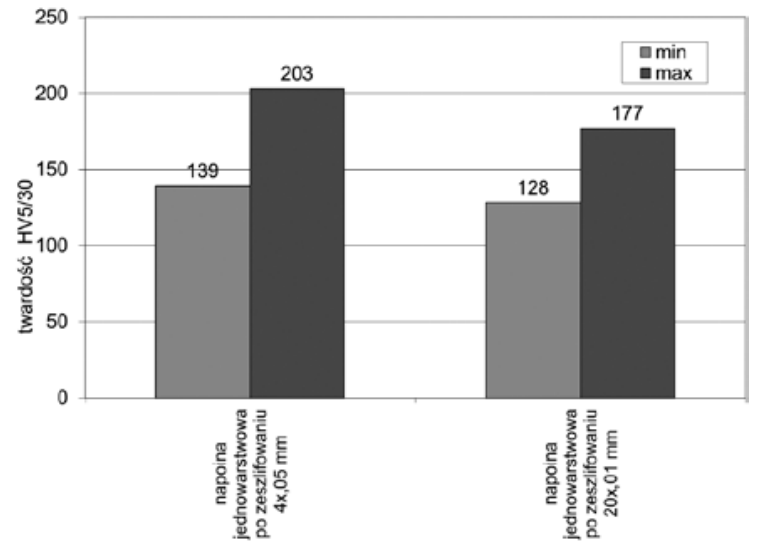

Rys. 5. Wpływ głębokości skrawania na twardość warstw napoin jednowarstwowych z brązu po obróbce przez szlifowanie

Fig. 5. Effect of grinding depth on the hardness of the monolayers of bronze padding welds

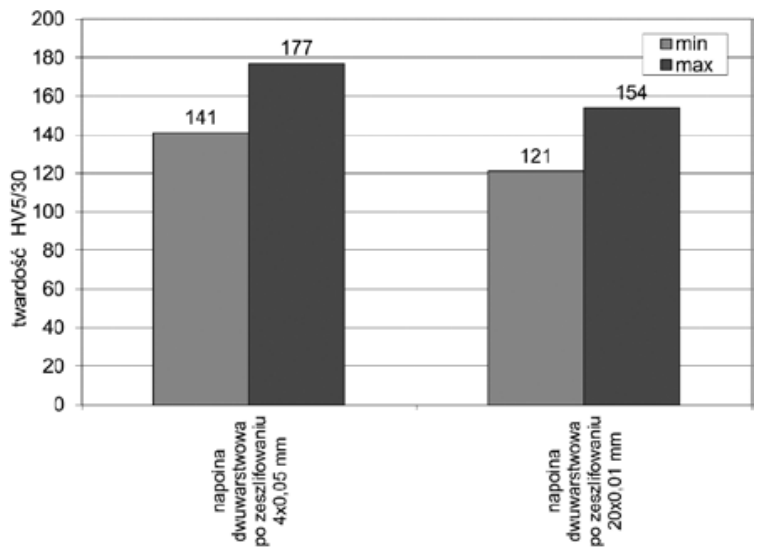

Rys. 6. Wpływ głębokości skrawania na twardość warstw napoin dwuwarstwowych z brązu po obróbce przez szlifowanie

Fig. 6. Effect of grinding depth on the hardness of the bilayers of bronze padding welds

W kolejnej próbie poddano badaniom czysty brąz odlany z drutu przeznaczonego do napawania. Uzyskany materiał na początku poddano obróbce przez frezowanie, a następnie zbierano warstwy materiału o różnej grubości jedynie przez szlifowanie. Uwzględniając wyniki z poprzedniej próby, w jednym przejściu tarcza ścierna zbierała warstwę o grubości tylko $0,01 \mathrm{~mm}$. Wyniki pomiarów twardości przedstawiono na rysunku 7 . Ze względu na niewielki rozrzut wyników, twardość podawano na wykresie jako wartość średnią z pięciu pomiarów.

Można zauważyć, że wartość twardości po frezowaniu jest większa od twardości stopiwa podawanego przez producenta o prawie $100 \mathrm{HV} 5 / 30$. Usuwanie warstwy materiału jedynie przez szlifowanie powoduje znaczący spadek twardości już dla grubości 0,5 mm zebranej warstwy, by dla grubości 1,2 mm osiągnąć wartości podane przez producenta drutu. Dalsza obróbka w głąb materiału (do 1,5 mm) nie powodowała już spadku twardości. Potwierdziły się w ten sposób sygnalizowane wcześniej informacje literaturowe [5], że zgniot spowodowany przez frezowanie wywołał ponaddwukrotny w stosunku do danych producenta wzrost twardości czystego brązu. Utwardzona warstwa materiału ma grubość rzędu $1 \mathrm{~mm}$.

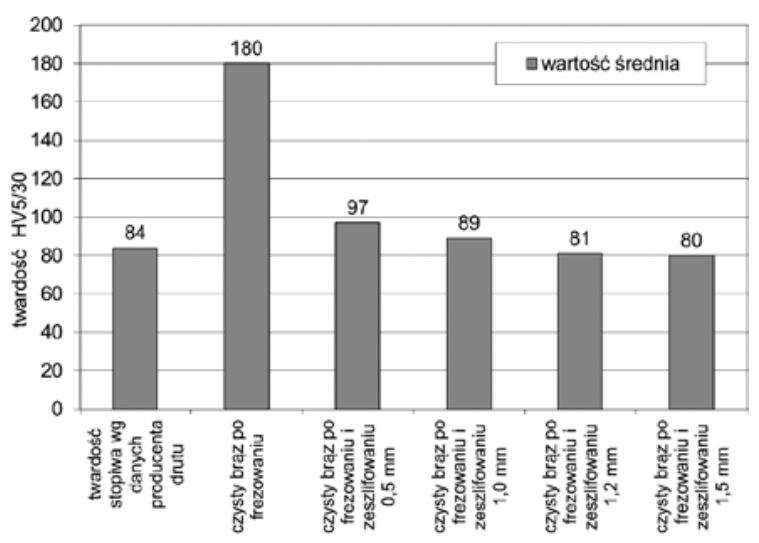

Rys. 7. Wpływ głębokości skrawania na twardość warstw napoin jednowarstwowych z brązu po obróbce przez szlifowanie

Fig. 7. Effect of grinding depth on the hardness of the monolayers of bronze padding welds

Na rysunkach 8 i 9 przedstawiono wyniki pomiarów twardości dla napoin w zależności od całkowitej grubości warstw materiału usuwanej przez szlifowanie. Pomiarów dokonano po usunięciu warstw o grubościach 0,5; 1 i 1,5 mm, przy czym w jednym przejściu głębokość skrawania wynosiła tylko 0,01 mm. Podobnie jak we wcześniejszej próbie dla napoin dwuwarstwowych mierzono twardość tylko w warstwie górnej napoiny.

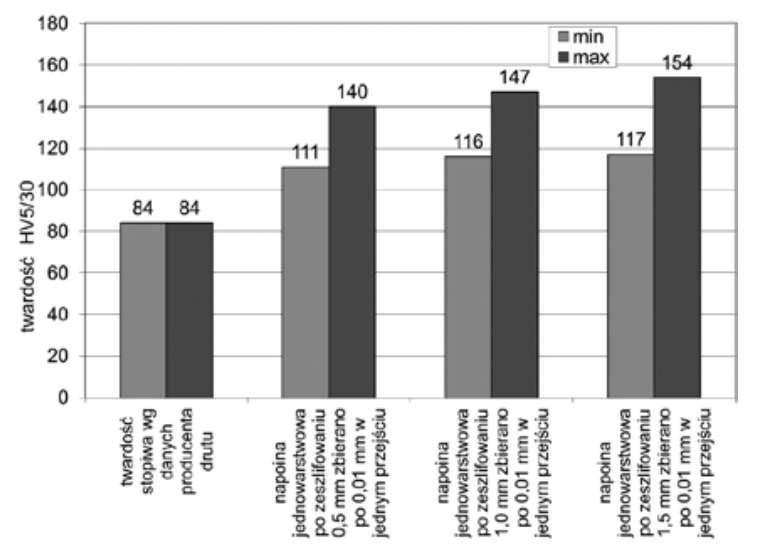

Rys. 8. Wpływ grubości warstwy zdejmowanej z próbek przez szlifowanie na twardość napoiny jednowarstwowej z brązu

Fig. 8. The influence of the thickness of removable layer by grinding on the hardness of monolayer bronze padding welds

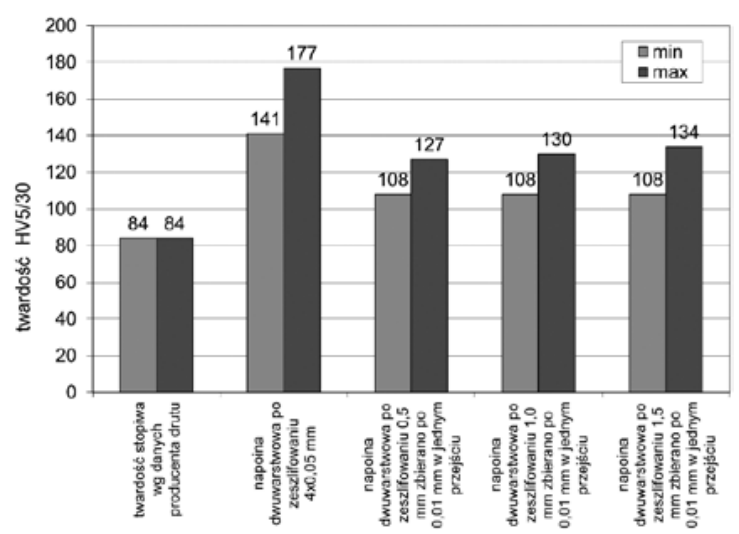

Rys. 9. Wpływ grubości warstwy zdejmowanej z próbek przez szlifowanie na twardość górnej części napoiny dwuwarstwowej z brązu Fig. 9. The influence of the thickness of removable layer by grinding on the hardness of bilayer bronze padding welds 
Obserwując wykres odnoszący się do napoiny jednowarstwowej (rys. 8), można zauważyć, że grubość warstwy usuwanej jedynie przez szlifowanie ma wpływ na twardość. Najmniejsze wartości twardości można uzyskać po zdjęciu $0,5 \mathrm{~mm}$, dalsza obróbka nie tylko nie zmniejsza twardości, ale wręcz podwyższa jej wartość. Prawdopodobnie spowodowane jest to powstaniem zgniotu przez zbyt długotrwałą obróbkę materiału. Najniższa mierzona twardość była jednak wciąż znacząco większa niż twardość stopiwa poda-

\section{Wnioski}

Na podstawie przeprowadzonych badań można stwierdzić wpływ liczby warstw na twardość brązu CuSn6 po napawaniu na podłoże stalowe. W wyniku wymieszania największe wartości twardości maksymalnej występują dla pojedynczego ściegu. Mniejsze wartości twardości występują dla napoiny jednowarstwowej i dolnej warstwy napoiny dwuwarstwowej. Najmniejszą twardość maksymalną uzyskuje się dla górnej warstwy napoiny dwuwarstwowej ze względu na brak bezpośredniego kontaktu łuku spawalniczego z materiałem podłoża.

Można takżezauważyć wpływ sposobu obróbkina twardość napoin. Przygotowanie próbek do badań jedynie przez obróbkę frezowaniem z zabieleniem wana przez producenta drutu.

Podobny efekt, choć nieco mniejszy niż dla próbek z napoinami jednowarstwowymi, obserwuje się dla napoin dwuwarstwowych (rys. 9). Wciąż także występuje różnica twardości próbek napoin w stosunku do twardości stopiwa.

Zarówno w przypadku napoin jedno-, jak i dwuwarstwowych ich twardość po frezowaniu z zabieleniem jest wyższa niż po obróbce szlifowaniem, co wynika z porównania rysunków 8 i 9 z rysunkiem 3.

Pracę wykonano w ramach badań statutowych nr 11.11.130.957.

\section{Literatura}

[1] Skorupa A., Krawczyk S., Góral T.: Badania własności tribologicznych napoin wielowarstwowych z brązu CuSn6 nakładanych na podłoże stalowe metodą MIG. Przegląd Spawalnictwa, nr 8/2007.

[2] Skorupa A., Góral T.: Wpływ technologicznych parametrów napawania na geometrię napoin z brązu układanych na podłożu stalowym metodą MIG. Przegląd Spawalnictwa, nr 3/2012. powoduje, że wyniki pomiarów są wyższe niż przy przygotowywaniu powierzchni przez szlifowanie.

Zwiększanie liczby kolejnych przejść tarczy szlifierskiej powoduje nieznaczny, ale systematyczny wzrost twardości napoiny. Z tego względu należy ograniczyć sumaryczną głębokość skrawania do niezbędnego minimum (w celu zapewnienia równoległości płaszczyzn pomiarowych próbki).

$\mathrm{Na}$ mierzoną twardość napoiny ma również wpływ grubość zbieranej warstwy materiału w jednym przejściu tarczy ściernej. Wzrost tej grubości powoduje istotne podwyższenie wyników pomiaru twardości. Skąd zalecić należy szlifowanie z małymi głębokościami skrawania, np. rzędu 0,01 mm.

Oba powyższe efekty wyjaśnić można wpływem zgniotu na twardość brązu cynowego.
[3] PN-EN ISO 6507-1 „Metale. Pomiar twardości sposobem Vickersa. Metoda badań".

[4] Przybylski W.: Obróbka nagniataniem. Technologia i oprzyrządowanie. WNT, Warszaw 1979.

[5] Przybyłowicz K.: Metaloznawstwo. WNT, Warszawa 1999. 